\title{
Commentary
}

\section{English as a Medium of Instruction in Asian Universities: The Case of Vietnam}

\author{
Le Duc Manh \\ Hai Phong University, Vietnam
}

\begin{abstract}
This article discusses the usage of English as a medium of instruction (EMI) at higher education institutions (HEIs) in Asia. In particular, the article aims to address the possible impacts of EMI at HEls. A case in Vietnam is used as an example for considering the prospective implementation and possible impacts of EMI. The author concludes that although EMI at HEls in Asia, Vietnam included, is an appropriate response to globalization, there are interfering factors at micro levels that must be thoroughly addressed to prevent educational failures that will seriously impact society in the long term.
\end{abstract}

Block and Cameron (2002, cited in Coleman, 2006) asserted that globalization has positive and negative effects on economics, culture, identity, politics, and technology. To meet the resulting demands in international and domestic labor markets, people everywhere need new skills. Tsui and Tollefson (2007, p. 1) used the term "global literacy skills" for technological and English skills, emphasizing that "to respond to the rapid changes brought about by globalization, all countries have been trying to ensure that they are adequately equipped with these two skills." Thus, student proficiency in the English language is important. Recently, many higher education institutions (HEls) in Asia have introduced English-medium programs. This article critically examines the relevance of the issue of English as a medium of instruction (EMI) at HEls in Asia and focuses on the possible positive and negative impacts of EMI.

\section{EMI at HEls in Asia}

In Asia, the adoption of EMI at HEls is considered the "policy fashion" (Byun, Chu, Kim, Park, Kim, \& Jung, 2011, p. 432) to attract foreign students, better equip domestic students for careers, and curb the high number of talented domestic students studying abroad in the era of internationalization. Accordingly, a number of HEls in Asia have reshaped their education policies to internationalize (Kirkpatrick, 2011) and have begun to offer English-medium programs. However, reports on the implementation of EMI reflect both positive and negative outcomes of this trend. While EMI students' language competence has significantly improved, they have received less support and instruction from professors (Byun et al., 2011) and have had difficulties understanding the subject content and fluently expressing their opinions (Chang,

Language Education in Asia, 2012, 3(2), 263-267. http://dx.doi.org/10.5746/LEiA/12/V3/I2/A14/Manh 
2010; Wu, 2006). Moreover, when discussing unintended negative effects of EMI, De Wit (2011) pointed out that there has been "a decline in the quality of education" (p. 6) because of a decreasing focus on other foreign languages and an insufficient focus on the quality of the English spoken by students and teachers whose native language is not English. Other pitfalls of EMI include serious divisions between Western-trained and local scholars (Shi, 2003, cited in Kirkpatrick, 2011), potential loss of indigenous cultures, and displacement and erosion of national languages (The Observatory on Borderless Higher Education, 2007).

Social inequality is another aspect of concern with EMI. The case of India is an example. There, EMI is believed to be advantageous for students from wealthy families which have used English for a generation or more, but disadvantageous for other students who do not have access to knowledge resources in English (Annamalai, 2004). Students who lack proficiency in English cannot adequately understand subjects taught in the language and thus may be poorly educated at university. Another issue is the "unequal linguistic dichotomy in terms of language ideology" (Annamalai, 2004, p. 190). English may be considered to represent modernity, progression, and high technology, whereas first languages may be seen as traditional and "as instruments that fulfill emotional needs and maintain cultural values and practices" (Annamalai, 2004, p. 190).

Regarding policy, EMI at HEIs in Asia is seen to be a top-down approach, with directives issued from higher levels to those who implement them (Gill, 2006). This is contradictory to Kaplan and Baldauf (1997) and Baldauf and Kaplan (2005)'s proposal that successful language-ineducation policies rely greatly on efforts from the bottom up. These scholars also suggest that objectives (e.g., access, personnel, curriculum, methods and materials, resourcing, community, and evaluation) be addressed at the level they are to be implemented. Discussing success in meeting these policies, Baldauf and Kaplan (2005) indicated that it "largely depends on policy decisions related to the teachers, the courses of study, and the materials and resources to be made available" (p. 1014). In each nation, these areas, in reality, develop depending on the way the educational system operates (Kaplan \& Baldauf, 1997). Malaysia is an interesting example to consider. EMI was proposed in this nation in 2005; however, the introduction of this language policy has been deemed sudden (Gill, 2006) and policy makers only "utilize the beliefs, values and interests of the individuals responsible for the policy," according to Zaaba, Ramadan, Anning, Gunggut, and Umemoto (2011, p. 163). Therefore, many Malaysian scholars and educators doubt the success of the implementation of EMI because of the lack of clarity with regard to its direction (Gill, 2006). Should EMI be unsuccessful, negative impacts on society, political and socioeconomic, are likely to occur.

\section{The Case of Vietnam}

The Government of Vietnam is devoted to enhancing its human resources in the age of global integration, technological advances, and internationalization. With the prime minister's recent approval of the Teaching and Learning Foreign Languages in the National Education System 2008-2020 project (Ministry of Education and Training, 2008), political will for such a move is obviously indicated. Accordingly, in the years leading up to 2015, the project proposes to begin EMI for approximately $20 \%$ of national, provincial, and other university students in certain subjects and sectors. The percentage of students and the number of schools and provinces will increase every year.

By 2020, all HEls will have intensive language training programs. Thus, although the idea of using EMI at HEls is considered a timely decision by the Vietnamese government in response to globalization, its implementation will not happen quickly. Employing Kaplan and Baldauf 
(1997) and Baldauf and Kaplan's (2005) previously presented policy areas, a number of interfering factors are discussed in the sections that follow.

\section{Student and Teacher Issues}

Examination of English language competency in Vietnam shows that students and lecturers have generally low English proficiency. For example, a recent notable investigation from Danang University (2012), one of the leading institutions in Vietnam, shows that $70 \%$ of the newly enrolled students have insufficient English proficiency to pursue studies in English. With such low English language competency, students would be unable to comprehend lectures or materials in English. Considering lecturers, few have the proficiency to verbally communicate in English. Lecturers who earned academic qualifications abroad appear to be good at English, although there are some concerns about their proficiency level, their ability to lecture at a level suitable for their students, and their interactions with students. If these concerns are not addressed, it may be difficult for students to learn from lecturers educated abroad.

\section{Curriculum Issues}

Curricula at HEls are considered outdated and inflexible (Dao, 2004) and the teaching methodology conventional and passive (Hayden \& Thiep, 2007). Nevertheless, since 2006, university education in Vietnam has experienced radical changes as some key HEls have embarked on so-called advanced programs using EMI to attract more students. However, in a recent paper, Hiep (2012) raised concerns about the shortcomings of these programs because of high tuition fees as well as teachers' and students' language competence.

\section{Socioeconomic and Political Impacts}

$\mathrm{EMI}$ at HEls in Vietnam are likely to cause socioeconomic inequality, since EMI seemingly benefits only the well-off minority of students with access to English. This policy marginalizes most students from rural areas because of their low level of proficiency in English. The technological and professional knowledge taught in English will be inaccessible to these linguistically disadvantaged students, who will subsequently be unable to compete for jobs on an equal basis with students who are fluent in English. In addition, they may not have the same opportunities for professional development and career advancement. Socioeconomic inequality may promote socioeconomic and political instability.

Finally, national identity needs consideration. With EMI at HEls and with companies preferring employees fluent in English, the long-term effect on the status of the Vietnamese language is in question. It may become a stepchild, or second-class, language. What will happen if EMI is at HEls for generations cannot be predicted.

\section{Conclusion}

In summary, the incentive for employing EMI at HEls is to produce a future labor force which is sufficiently qualified in terms of professional knowledge and foreign-language competence to meet the requirements demanded of human resources in the current epoch. For the successful implementation of EMI at HEls, sociolinguistic research in the local context, as suggested by Kaplan and Baldauf (1997), would provide policy makers, educational administrators, and curriculum developers with insight into the issues involved, so that university students will be better equipped to acquire English language proficiency and learn in their EMI courses. 


\section{Author Note}

Le Duc Manh, Department of Foreign Languages, Hai Phong University, Hai Phong, Vietnam.

Correspondence concerning this article should be addressed to Le Duc Manh, Department of Foreign Languages, Hai Phong University, 171 Phan Dang Luu, Kien An, Hai Phong, Vietnam. E-mail: manhducle_hpu@yahoo.com 


\section{References}

Annamalai, E. (2004). Medium of power: The question of English in education in India. In J. W. Tollefson \& A. B. M. Tsui (Eds.), Medium of instruction policies (pp. 177-194). Mahwah, NJ: Lawrence Erlbaum Associates.

Baldauf, R. B. Jr., \& Kaplan, R. B. (2005). Language-in-education policy and planning. In E. Hinkel (Ed.), Handbook of research in second language teaching and learning (Vol. 1, pp. 10131034). Mahwah, NJ: Lawrence Erlbaum Associates.

Byun, K., Chu, H., Kim, M., Park, I., Kim, S., \& Jung, J. (2011). English-medium teaching in Korean higher education: Policy debates and reality. Higher Education, 62(4), 431-449. http://dx.doi.org/10.1007/s10734-010-9397-4

Chang, Y.-Y. (2010). English-medium instruction for subject courses in tertiary education: Reactions from Taiwanese undergraduate students. Taiwan International ESP Journal, 2(1), 55-84.

Coleman, J. A. (2006). English-medium teaching in European higher education. Language Teaching, 39(1), 1-14. http://dx.doi.org/10.1017/S026144480600320X

Danang University. (2012). Trình độ ngoại ngũ của sinh viên quá yếu[Students' language competence is too low]. Retrieved from http://dhdn.hirevietnamese.com/posts/view/226/239

Dao, N. V. (2004, October 16). Giáo dục đại học VN - một vài suy nghĩ [Higher education in Vietnam Some concerns]. Tuoi Tre. Retrieved from http://tuoitre.vn/Giao-duc/51862/Giao-duc-daihoc-VN---mot-vai-suy-nghi.html

De Wit, H. (2011). Internationalization misconceptions. International Higher Education, 64(1), 6-7.

Gill, S. K. (2006). Change in language policy in Malaysia: The reality of implementation in public universities. Current Issues in Language Planning, 71), 82-94. http://dx.doi.org/10.2167/cilp083.0

Hayden, M., \& Thiep, L. Q. (2007). Institutional autonomy for higher education in Vietnam. Higher Education Research and Development, 26(1), 73-85. http://dx.doi.org/10.1080/07294360601166828

Hiep, P. (2012, 23 September). More university courses in English, in internationalisation drive. University World News. Retrieved from http://www.universityworldnews.com/article.php?story=2012091915181783

Kaplan, R. B., \& Baldauf, R. B., Jr. (1997). Language planning from theory to practice. Sydney, Australia: Multilingual Matters.

Kirkpatrick, A. (2011). Internationalization or Englishization: Medium of instruction in today's universities. Working Paper Series 2011/003. Centre for Governance and Citizenship, the Hong Kong Institute of Education. http://repository.ied.edu.hk/dspace/handle/2260.2/6224

Ministry of Education and Training, Vietnam. (2008). Dạy và học ngoại ngũu trong hệ thống giáo duc quốc dân giai doạn 2008-2020 [Teaching and learning foreign languages in the national education system 2008-2020] Retrieved from http://vanban.moet.gov.vn/?page=1.15\&708\&opt=brpage

The Observatory on Borderless Higher Education. (2007). The growth of English-medium instruction in East Asia: The key to competitiveness? Retrieved from http://www.obhe.ac.uk/documents/view_details?id=195

Tsui, A. B. M., \& Tollefson, J. W. (2007). Language policy and the construction of national cultural identity. In A. B. M. Tsui \& J. W. Tollefson (Eds.), Language policy, culture, and identity in Asian contexts (pp. 1-24). Mahwah, NJ: Lawrence Erlbaum Associates.

Wu, W. S. (2006). Students' attitude toward EMI: Using Chung Hua University as an example. Journal of English and Foreign Language and Literature, 4(1), 67-84.

Zaaba, Z., Ramadan, F. I., Anning, I. N. A., Gunggut, H., \& Umemoto, K. (2011). Language-ineducation policy: A study of policy adjustment strategy in Malaysia. International Journal of Education and Information Technologies, 5(2), 157-165. 